TTR

Traduction, terminologie, re?daction

\title{
Fidelity and The Gendered Translation
}

\section{Rosemary Arrojo}

Volume 7, numéro 2, 2e semestre 1994

Traduire les sociolectes

URI : https://id.erudit.org/iderudit/037184ar

DOI : https://doi.org/10.7202/037184ar

Aller au sommaire du numéro

\section{Éditeur(s)}

Association canadienne de traductologie

\section{ISSN}

0835-8443 (imprimé)

1708-2188 (numérique)

Découvrir la revue

\section{Citer cet article}

Arrojo, R. (1994). Fidelity and The Gendered Translation. TTR, 7(2), 147-163. https://doi.org/10.7202/037184ar

\section{Résumé de l'article}

Fidélité et traduction " sexuale » — Les théories postmodernes du langage ont radicalement changé la manière d'envisager la tâche du traducteur et les relations établies entre l'original et ses versions étrangères. L'un des apports les plus importants de ces théories du texte est de souligner que l'acte de traduire implique inévitablement la production des signifiés. Simultanément, la reconnaissance accrue de l'impact des facteurs sexuaux sur la production du sens est l'amorce d'une heureuse union entre le féminisme, les théories contemporaines du texte et la traductologie en émergence. Cette union a commencé à produire un nouveau type de traductions politiquement motivées, ainsi qu'une réflexion sur la traduction et les rôles sexuaux, et a incité certaines traductrices à décrire leur pratique et leurs stratégies féministes, par lesquelles elles subvertissent explicitement l'original lorsqu'il ne leur convient pas. Cependant - et telle est ma thèse - , même si leurs travaux et leurs commentaires théoriques prouvent que leur voix a déjà conquis un espace mérité dans le scénario essentialiste (encore) dominant de la culture patriarcale, elles semblent reproduire une variante du même scénario qui traite l'original et les traductions différemment, ce qu'elles condamnent pourtant dans les théories traditionnelles de la traduction et des rôles sexuaux - et avec raison. Déguisant leur intervention délibérée sous le masque d'un original - un autre ou le même, qu'elles déconstruisent de façon explicite elles ne prennent pas au sérieux leurs hypothèses pourtant pertinentes, ce qui risque inutilement de compromettre leurs travaux.

Tous droits réservés ( $\mathrm{TTR}$ : traduction, terminologie, rédaction — Les auteurs, Ce document est protégé par la loi sur le droit d’auteur. L’utilisation des 1994

services d'Érudit (y compris la reproduction) est assujettie à sa politique d'utilisation que vous pouvez consulter en ligne.

https://apropos.erudit.org/fr/usagers/politique-dutilisation/ 


\section{Fidelity and The Gendered Translation $^{1}$}

\section{Rosemary Arrojo}

Feminism comes to be defined here almost inadvertently, as a bond of reading: a bond of reading that engenders, in some ways, the writer - leads to her full assumption of her sexual difference: a bond of reading and of writing which, however, paradoxically precedes knowing what it means to "read as a woman," since this very bond, this very reading, is precisely constituted by the recognition that the question "what is a woman?" has not yet been answered and defies, in fact, all given answers.

What Does a Woman Want? Reading and Sexual Difference, Shoshana Felman

While tradition has generally viewed translation as a transparent, impersonal activity which is expected to recover - and to be blindly faithful to - the supposedly stable meanings of an author, contemporary, postmodern theories of language are beginning to

1. A preliminary version of this paper was presented at the conference "Woman, Text, Image," sponsored by the Department of Romance Languages and Literatures, Binghamton University, New York, U.S.A., on April 16, 1994. It is part of a research project sponsored by CAPES (Coordenação de Aperfeiçoamento de Pessoal de Nivel Superior), of the Brazilian Ministry of Education and conducted at the Department of Comparative Literature of Yale University from October of 1993 to September of 1994. I thank my colleague Paulo Ottoni for his help with the French version of my abstract. 
recognize the inevitable echoes of the translator's voice in the translated text. At the same time, an increasing awareness of the impact of gendered related issues to the production of meaning and knowledge is beginning to encourage a promising union between feminism, postmodernism, and the emerging discipline of translation studies. An outstanding example of such a union can be found in Lori Chamberlain's often quoted essay on "gender and the metaphorics of translation" which has called our attention to the implications of the traditional, "masculine" opposition between productive and reproductive work for the ways in which patriarchal culture views translators and their work, at the same time that it has allowed us to examine "what is at stake for gender in the representation of translation: the struggle for authority and the politics of originality informing this struggle" (1988, p. 455). The "sexualization of translation" appears, for instance, in an exemplary fashion, in the well-known tag les belles infideles: "like women, the adage goes, translations should be either beautiful or faithful." Such a tag, argues Chamberlain, "owes its longevity" mainly to the fact that it "has captured a cultural complicity between the issues of fidelity in translation and in marriage":

For les belles infidèles, fidelity is defined by an implicit contract between translation (as woman) and original (as husband, father, or author). However, the infamous "double standard" operates here as it might have in traditional marriages: the "unfaithful" wife/translation is publicly tried for crimes the husband/original is by law incapable of committing. This contract, in short, makes it impossible for the original to be guilty of infidelity. Such an attitude betrays real anxiety about the problem of paternity and translation; it mimics the patrilineal kinship system where paternity - not maternity legitimizes an offspring. (1988, pp. 455456)

As the authorial role of the translator is recognized, as "reproduction" is conceived to be in fact a form of "production," and as the traditional opposition between the so-called "original" and its translation is deconstructed, the "struggle for authority" that takes place in any form of reading necessarily entails a revision of our familiar conceptions of fidelity owed to the "original." From such 
a perspective, the main goal of this paper is to examine the views on fidelity and on the relationships that can be established between "original" and translation as expressed by some female translators who share not only an awareness of their gendered voices but, mainly, of the political responsibilities associated to such voices. As they reflect on their own work and defend their active, interventionist role in the translations they do, they also seem to claim some form of allegiance to the traditional maxim of translation ethics which prescribes the protection of the author's (or the text's) original meaning at all costs. In the defense of their authorial role in the production of meaning that constitutes their work of translation, such female translators seem to fall into another version of the same "infamous double standard" that can be found in our traditional, "masculine" theories and conceptions of translation. In such a context, which seems to repeat some of the basic contradictions that often haunt the contemporary reflection on gender inspired by postmodernism, I shall propose to answer a basic question: since it does not seem to be theoretically coherent to reconcile the awareness of the translator's "audible" voice in the translated text with the traditional notion of fidelity allegedly owed to the "original," what kind of ethics could we envision for the consciously gendered translation? What kind of "fidelity" can the politically minded, feminist translator claim to offer to the authors or texts she translates and deconstructs?

The recognition of translation as a form of écriture, as a production rather than a mere recovery of someone else's meaning, which we owe to postmodern theories of language, is a key factor for politically active, feminist translators. While traditionally regarded as marginal and secondary, in the wake of contemporary theories of knowledge and culture, both women's and translation issues have become "tools" for a critical understanding of language and, when combined, "form the basis for a new and exciting poetics," as David Homel and Sherry Simon point out (1988, p. 43). A poetics, however, which is also a political practice. This productive, "visible" translator does not alienate her work from her convictions and her activism and, quite on the contrary, takes on an explicitly authorial role. As Luise von Flotow observes, "the modest, 
self-effacing translator who produces a smooth, readable target language version of the original has become a thing of the past" $(1991, \text { p. } 76)^{2}$. For Barbara Godard, the notion of translation as production "is at odds with the long-dominant theory of translation as equivalence and transparency which describes the translator as an invisible hand mechanically turning the words of one language into another" (Homel and Simon, 1988, p. 50). According to Susanne de Lotbinière-Harwood (1990), "making the feminine subject visible in language is an important way of putting feminist politics into practice," and since "language cannot be neutral," she is aware of the fact that her "woman-centred focus guides and frames her translation work":

as a feminist translator, my choices - of words, of works to take on - are informed by the emerging women's culture, which means that our references can now be found within the sphere of work done by women. We have a feminist dictionary, an encyclopedia, theoretical works, fiction, criticism, translations, prefaces to translations - all of these are beginning to constitute a women's culture. (pp. 43-44)

As Barbara Godard theorizes, in feminist translation, "difference" is no longer "a negative term," and translation becomes what she calls a "transformance":

2. The recognition of the translator's "visibility" in the texts she or he translates is one of the most important consequences of a reflection on translation and on reading inspired by postmodernist theories of language which have questioned the possibility of any simple, recoverable origin. Jacques Derrida's "deconstruction" has been particularly efficient in revising the ways tradition has always confined translation to a plot of failure and impossibility. Derrida explicitly addresses the theoretical issues posed by translation in texts such as The Ear of the Other, "Living on/Border Lines" and "Des Tours de Babel." For a more specific discussion about the question of the translator's visibility itself, see also Arrojo (1993) and Venuti (1986). 
Like parody, feminist translation is difference despite similarity. As feminist theory tries to show, difference is a key factor in thought processes and in critical activity. The feminist translator affirming her critical difference, her delight in interminable rereading and re-writing, flaunts the signs of her manipulation of the text. Womanhandling the text in translation means replacing the modest, self-effacing translator. The translator becomes an active participant in the creation of meaning. (p. 15)

In a similar manner, Suzanne Jill Levine associates her work as a translator to what she considers to be Julia Kristeva's option for "woman's dissidence, for feminine subversion as a process of becoming." In her translation practice, Levine opts for "subersive" strategies particularly when translating Guillermo Cabrera Infante's sexist novel La habana para un infante difunto, which, in her own words, not only "mocks" and "manipulates" "women and their words," but which is also "unabashedly pronographic" and "explicitly" exposes "the sterility of the archetypal relationship between man and woman":

Like the mythic Narcissus who rejects Echo's caresses, this modern Narcissus [Infante] only wishes to listen to his Echo. [...] The narrator is a supremely solitary figure, like the pavo real, the peacock from which the pavane, a courtly and often solo dance, originates. He is enclosed in his book, in his lonely hall of mirrors like King Christophe; the greatest moment of love, or, rather, orgasm, he experiences, as he says, is through masturbation. (1983, pp. 91-92)

"Where does this leave a woman as translator of such a book? Is she not a double betrayer, to play Echo to this Narcissus, repeating the archetype once again?" asks Levine. The answer she offers us is the conviction that her only alternative is to become a traduttora traditora: "because of what is lost and can be gained in crossing the language barrier, because of the inevitable rereading that occurs in transposing a text from one context to another, a translation must subvert the original" (p. 92). 
Obviously, such notions of translation as "production," "subversion," "manipulation," or "transformance" must also bring about a radically different relationship with the text's supposedly "original meaning" or with its author. As Levine suggests, if translation functions as a form of subversion, the translator is necessarily a "betrayer" or, at best, also an author of the text she translates. A few examples from her own practice are worth quoting:

When the Havana narrator makes the jaded statement "no one man can rape a woman," the infernal translator undermines this popular myth with the book's own corrosive mechanism of alliteration and writes: "no wee man can rape a woman." Since $L a$ habana para un infante difunto mocks popular sexual mythology, subverts traditional narrative, and sets verbal reality above all others, the more subversive Infante's Inferno is, the better. Verbal logic supplants fidelity when "fines de siglo" is translated not as "turn of the century" but as the "gay nineties," or when "Amor Propio" (the title initiating a chapter in praise of masturbation) is translated not as amour-propre, self-esteem or self-love, but as "Love Thyself." (pp. 92-93)

As an "infernal translator," as a consciously motivated traduttora traditora, Levine deliberately rewrites Infante's text and turns a novel which "mocks" and "manipulates" "women and their words" into one that mocks and manipulates men and their words. However, more than simply "subverting" the text she translates, Levine seems to be convinced that she can actually be "faithful" in her betrayal as she supposedly "undermines" her sexist "original" with, among other things, "the book's own corrosive mechanism of alliteration." That is, she seems to be convinced that her "subversive" intervention in Cabrera Infante's text not only allows her to express her own criticism of the "original" but also to claim some form of "fidelity" to the text she translates, a claim which is further supported by her alleged "collaboration" with Cabrera Infante.

This ambivalent, rather opportunistic brand of "faithfulness" finds support in Lori Chamberlain's above quoted essay, in which Levine's version of La habana para un infante difunto is cited as an 
example of what should be an essential requirement of a "feminist theory of translation":

What is required for a feminist theory of translation is a practice governed by what Derrida calls the double bind - not the double standard. Such a theory might rely, not on the family model of oedipal struggle, but on the double-edged razor of translation as collaboration, where author and translator are seen as working together, both in the cooperative and the subversive sense. (1988, p. 470)

If this "double standard," which has treated "originals" and translations differently, is to be eliminated from a theory of translation that could be called "feminist," we should examine more closely the implications of Levine's strategies and comments particularly as they are elected by Chamberlain as exemplary and as they are implicitly contrasted with the supposedly "violent" moves of a male translator. As Chamberlain examines the overlapping between the politics of colonialism and the politics of gender at work in traditional, patriarchal notions of translation, she cites as an example an English translation of Horace done during the sixteenth century when translation was seen as a "public duty" that justified any form of disregard for the "original" and its culture. The translator in question is Thomas Drant who, "in the preface to his translation of the Roman author, boldly announces":

First I have now done as the people of God were commanded to do with their captive women that were handsome and beautiful: I have shaved off his hair and pared off his nails, that is, I have wiped away all his vanity and superfluity of matter [...] I have Englished things not according to the vein of the Latin propriety, but of his own vulgar tongue [...] I have pieced his reason, eked and mended his similitudes, mollified his hardness, prolonged his cortall kind of speeches, changed and much altered his words, but not his sentence, or at least (I dare say) not his purpose. (Amos, 1973, pp. 112-113; quoted in Chamberlain, 1988, p. 460)

As Chamberlain aptly comments, in Drant's translation, "fidelity" defines "a (male) author-translator's relation to his (female) mother 
tongue, the language into which something is being translated. In this case, the (female) language must be protected against vilification": "It is, paradoxically, this sort of fidelity that can justify the rape and pillage of another language and text" (1988, p. 461). However, if Drant's "appropriation" of Horace's text can be associated to colonialism and rape, it seems difficult to avoid the fact that Levine's "womanhandling" of Infante's text can also remind us of an act of "castration" which is "justified" by the feminist need to subvert an obviously sexist "original." In the examples I have quoted above from Levine's translation, the "original" "no one man can rape a woman" becomes "no wee man can rape a woman," while in Drant's translation of Horace, the "original" loses his "hair," "nails," and "all his vanity and superfluity of matter."

While Levine justifies her intervention in Cabrera Infante's text on the grounds that it goes along with the text's own "verbal logic," Drant claims that although he has "changed and much altered" Horace's words, he has not changed his "sentence," nor his "purpose." In other words, both Levine and Drant consciously "invade" and interfere with the texts they translate and make them suit their own ideological interests and perspectives at the same time that they disguise their "subversion" under the mask of some form of respect to the "original." Therefore, it seems fair to conclude that, in spite of her groundbreaking insights into some intersections between translation and gender, Chamberlain judges both Levine's and Drant's translations and statements on the basis of the same "double standard" she proposes to eliminate from theories of translation. After all, on what basis, other than her own feminist "bias," can Chamberlain claim that the "violence" of translation is restricted to male translators and patriarchal translation theories? In other words, why isn't Levine's intervention in Infante's text also recognized as a "struggle for authority," as a struggle for the right to possess and determine meaning, in spite of the author and of the "fidelity" that is supposedly owed to him or her? Why is such a struggle masked as a form of "subversive collaboration" with the author while Drant's "intervention" in Horace's text is solely an act of violence against the "original"? 
Another example worth examining is provided by Luise von Flotow (1991) who invites us to reflect on a translation problem: how to translate "Ce soir, $j$ 'entre dans l'histoire sans relever ma jupe," a line from the play La Nef des sorcières, written and produced in 1976 by a group of feminist writers in Quebec. As she tells us, "there are two translators available for the job." David Ellis, "with more or less traditional views on the importance of "fidelity' and equivalence in translation," and who believes that a translator's work "should be seen through, and not heard about," renders this line from the play as follows: "This evening I'm entering history without pulling up my skirt." Linda Gaboriau, the "feminist translator," on the other hand, translates the same line as "This evening I'm entering history without opening my legs" (p. 70) ${ }^{3}$. In her comparison of the two versions, Barbara Godard (1984) recognizes that the feminist translator's has "a greater shock effect," even though it is, in its own way, more faithful to feminist interests by making explicit "a major feminist topos, namely the repossession of the word; the naming and writing of the life of the body, the exploration of its images, as experienced by women" (p. 14).

"Feminist translation" is, for von Flotow (1991), coherent with the kind of writing feminist authors have been producing in Quebec since the 1970's, and which has had as its main target the deconstruction of the "conventional and prescriptive patriarchal language" in order for "women's words to develop, find a space and be heard" (p. 73). Like the feminist writers they translate, feminist translators have given themselves "permission to make [their] work visible, discuss the creative process [they are] engaged in, collude with and challenge the writers [they] translate" (p. 74). Among the "strategies" used by these translators to become "visible" in the work they do, the practice of what von Flotow calls "hijacking" is particularly significant. As she explains, she has taken the term from David Homel, a translator himself, who "attacks Susanne de Lotbinière-Harwood for her excessive interference" in the translation

3. The same translation "problem" was previously commented on by Évelyne Voldeng (1983) and by Barbara Godard (1984). 
of Lettres d'une autre, by Lise Gauvin (Homel, 1990). According to von Flotow (1991), for Homel, Gauvin's book has become an "informal textbook on contemporary Quebec culture" and has been "ideologically corrected (i.e. feminized), beyond the author's original intention" (p. 78). In her response to Homel, de LotbinièreHarwood wrote:

Lise Gauvin is a feminist, and so am I. But I am not her. She wrote in the generic masculine. My translation practice is a political activity aimed at making language speak for women. So my signature on a translation means: this translation has used every possible translation strategy to make the feminine visible in language. Because making the feminine visible in language means making women seen and heard in the real world. Which is what feminism is all about. (De Lotbinière-Harwood, 1990, p. 9; quoted in von Flotow, 1991, p. 79)

As von Flotow comments, de Lotbinière-Harwood "has in fact 'hijacked' the text, appropriated it, made it her own to reflect her political intentions." And, as we are told, since her translation "won the prize awarded for the translation of French-Canadian literature by Columbia University in 1991," "in this case, the translator's collusion with the author is [...] of secondary importance. Here the translator is writing in her own right" (1991, p. 80).

The justification of such a brand of "feminist translation" is also based on what von Flotow refers to as a "Derridian revision of key concepts in Western philosophy," which "has stimulated renewed interest in the work of the translator, and endowed her with the right, even the duty to 'abuse' the source text" (p. 80). Besides Derrida's deconstruction, "the influence of second-wave feminism has been vital for feminist translation. It has endowed both Quebec feminist writers and their translators with the authority and the means to disregard Authority" (p. 81). Finally, she also quotes Lori Chamberlain's "Gender and the Metaphorics of Translation" and her examination of traditional tropes used for translation which have "routinely used metaphors of rape and violence against women and of paternalistic control to maintain [the] difference [...]" (von Flotow, 1991, pp. 81-82) in value between the original and its 
'reproduction' (p. 81). In doing so, such metaphors "have reflected the power relations between the sexes, and revealed the fear of the maternal (or the mother tongue), the need to protect (control) it as well as the need to retain the ownership of offspring (texts)" (p. 82). Like Suzanne Jill Levine's and Lori Chamberlain's, Luise von Flotow's conception of a "feminist" strategy of translation is based on a double standard. At the same time that she sees violence in the patriarchal, logocentric tropes that have reduced the translator's role to an impossibly neutral recovery of someone else's meaning, she considers "hijacking" to be a desirable and, we may assume, nonviolent approach for the kind of translation pursued by feminists. In other words, and once again, on what grounds can one justify that "womanhandling" texts is objectively positive while "manhandling" them is to be despised? In what terms is the trope of translation as "hijacking" non-violent? Why isn't the feminist translator's appropriation of the "original" also a symptom of "the need to retain the ownership" of meaning?

Moreover, the "Derridian revision of key concepts in Western philosophy" has indeed "stimulated renewed interest in the work of the translator" but it has not, by any means, "endowed" the female translator with "the right and even the duty to 'abuse' the source text," as Von Flotow would have it. From the voluminous, complex work produced by Derrida, I shall look for some validation in a short "letter" he wrote to a Japanese professor, in which he tries to explain why he himself cannot come up with the ultimate, the absolutely correct translation (or explanation) of "deconstruction," the very word which has defined his philosophy:

To be very schematic I would say that the difficulty of defining and therefore also of translating the word "deconstruction" stems from the fact that all the predicates, all the defining concepts, all the lexical significations, and even the syntactic articulations, which seem at one moment to lend themselves to this definition or to that translation, are also deconstructed or deconstructible, directly or otherwise, etc. And that goes for the word, the very unity of the word deconstruction, as for every word. (1991, p. 274) 
It seems that what Jacques Derrida's deconstruction has relentlessly showed is that no meaning can ever be stable nor "original," no meaning can ever be free from the perspective and the context in which it is produced and, therefore, no meaning can ever be "reproduced" or "recovered" but is, instead, always already created, or recreated, anew. Thus, if any reading or any translation is inevitably also a form of "original" writing, which will have to be reread, retranslated and rewritten over and over again, the implications of Derrida's deconstructive reflection for the translator's task radically change the traditional conceptions of fidelity and of the relationships that can be established between translations and originals.

The "Derridian revision of key concepts in Western philosophy" cannot "endow" the female translator "with the right and even the duty to 'abuse' the source text" simply because every contact between any subject and what we may call "meaning" is inevitably marked by some form of "abuse" or "violence." That is, even if a translator's conscious goal is nothing but to be "invisible" and, therefore, to recover and to reproduce the totality of his author's "original" meaning, the only possible outcome of such a project is the translator's own view - the translator's own "writing" - of what the allegedly "original" meaning is supposed to be. As Derrida's "letter" suggests, not even the "original" author herself could produce a totally faithful, non-abusive translation of any of her texts precisely because there is nothing definite or stable that one can be faithful to once and for all. As Barbara Johnson concludes in her reflection on the implications of Derrida's philosophy for translation, "it is [...] precisely the way in which the original text is always already an impossible translation that renders translation impossible" (1985, p. 146). In this sense, translation is truly subjected to what we could call, via Derrida, a "double bind," that is, it is, at the same time and in some level, both possible and impossible, both protective and abusive, both faithful and unfaithful, both a production and a re-production of meaning. Thus, being "unfaithful" to the "original" cannot be merely a "right," or a "duty"; it is every translator's and every reader's inevitable fate, it is precisely that which cannot be avoided. Of course that in the case 
of the feminist translators here examined, "unfaithfulness" is an openly political strategy and a conscious option, which is, however, also transformed into some form of "faithfulness" or "collaboration," whenever it is convenient. If "unfaithfulness" is a conscious, political choice, its implicit, metaphorical "violence" cannot be simply taken for an alternative form of fidelity to a text with which a feminist translator cannot completely agree, or that she intends to openly subvert. At the same time, such an intervention, like any other, and particularly for being deliberate, is undeniably the necessary outcome of the struggle to possess meaning which constitutes any act of reading and cannot be regarded as absolutely more legitimate or less "violent" than non-feminist translation strategies. After all, one needs a bizarre sense of ethics in order to be able to claim "faithfulness" to a text one consciously decides to "hijack" or to "castrate."

From the perspective opened up by non-essentialist textual theories, which recognize the productive nature of any act of reading or translation, we can say that the feminist translators' explicitly authorial strategies to take over the texts they translate are perfectly legitimate within the political context they are so bravely fighting to construct. Their successful determination to make themselves "visible" in the texts they translate is a clear sign that both translation and women's issues have conquered a much deserved space within the prevailing, phallogocentric world of men and alleged "originals." However, the validation of the "abuse" to which they submit their "originals" is not to be found either in Derrida's deconstruction or in their authors' approval or collaboration. It can only come (and indeed it has come) from the communities that are ready to accept or absorb "the emerging women's culture" and which share or sympathize with the same values and political interests. Such communities are, thus, not only equipped to accept their translations and comments as legitimate but also have the authority to publish and celebrate them. However, such translations cannot be absolutely acceptable, as they are not absolutely more "noble," or more justifiable than the patriarchal translations and notions they are trying to deconstruct. In fact, the double standard on which some of the feminist translators here discussed base their 
comments and theoretical statements can actually undermine their most sound and liberating insights as they sometimes seem to repeat the same essentialist strategies and conceptions they explicitly reject. As I have tried to argue, their open, "subversive" interference in the texts they translate serves goals that are quite similar to the ones they so vehemently attack in what they call male, colonialist modes of translating. Like every translator, whether acting consciously or unconsciously, what the feminist translator cannot help doing is to take over the author's role as she translates. Thus, the only kind of fidelity we can possibly consider is the one we owe to our own assumptions, not simply as individuals, but as members of a cultural community which produces and validates them. And each one of the female translators here discussed is truly faithful to the values that constitute the communities which have accepted and praised them. If meaning cannot be intrinsically stable, if every meaning is always already a translation that fails to protect that which could be called an "origin" and, therefore, if it cannot be forever "attached" to our writings, readings or translations, then any other kind of fidelity is but an illusion. If the recognition of the translator's authorial role is to be taken seriously, if translations should finally begin to give up their marginal status, both our practice and theoretical statements should encourage not only a more realistic relationship between "originals" and their versions, but also a more reliable - and less hypocritical - notion of ethics so that the delicate bond that inevitably brings together (and apart) authors and translators could finally begin to be negotiated with less anxiety. After all, if we cannot be really faithful to the texts we translate, if we cannot avoid being faithful to our own circumstances and perspective, we should simply make an effort to accept and be open about our "infidelities" and try to forget the unnecessary guilt they bring.

Universidade Estadual de Campinas, Brazil

\section{Works Cited}

AMOS, Flora Ross (1973). Early Theories of Translation. New York, Octagon Books. [1 ${ }^{\text {st }}$ ed.: 1920] 
ARROJO, Rosemary (1993). "A Tradução Passada a Limpo e a Visibilidade do Tradutor," Tradução, Desconstrução e Psicanálise. Rio de Janeiro, Ática, pp. 71-89.

BROSSARD, Nicole, France Théoret et al. (1976). La Nef des sorcières. Montréal, Quinze.

CHAMBERLAIN, Lori (1988). "Gender and the Metaphorics of Translation." Signs : Journal of Women in Culture and Society, XIII(3), pp. 454-472.

DE LOTBINIĖRE-HARWOOD, Susanne (1990). Preface to Lise Gauvin's Letters from Another. Toronto, Women's Press.

DERRIDA, Jacques (1982). "Living on/Border Lines," in Geoffrey Hartman, ed., Deconstruction and Criticism. New York, The Seabury Press.

(1985a)."Des Tours de Babel," in Joseph Graham, ed., Difference in Translation. Ithaca, Cornell University Press, pp. 165207.

(1985b). The Ear of the Other - Otobiography, Transference, Translation. Trans. by Peggy Kamuf. New York, Schocken Books.

(1991). "Letter to a Japanese Friend," in Peggy Kamuf, ed., A Derrida Reader - Between the Blinds. New York, Columbia University Press, pp. 271-275.

FELMAN, Shoshana (1993). What Does a Woman Want? Reading and Sexual Difference. Baltimore, The Johns Hopkins University Press.

GODARD, Barbara (1984). "Translating and Sexual Difference." Resources for Feminist Research, XIII(3), pp. 13-16. 
HOMEL David and Sherry SIMON, eds. (1988). Mapping Literature - The Art and Politics of Translation. Montréal, Véhicule Press.

HOMEL, David (1990). "Lise Gauvin Astutely Explains Quebec to Outsiders," The Gazette, April 21st.

JOHNSON, Barbara (1985). "Taking Fidelity Philosophically," in Joseph Graham, ed., Difference in Translation. Ithaca, Cornell University Press, pp. 142-148.

LEVINE, Suzanne Jill (1983). "Translation as (Sub)Version: On Translating Infante's Inferno," Sub-stance, 42, pp. 85-93.

VENUTI, Lawrence (1986). "The Translator's Invisibility," Criticism, XXVIII(2), Spring, pp. 179-212.

VOLDENG, Évelyne (1983). "La Traduction poétique: duplication ou dérivation textuelle d'une langue à une autre?" in A. Thomas and J. Flamand, eds., La Traduction: l'universitaire et le praticien. Ottawa, Éditions de l'Université d'Ottawa, pp. 150-159.

VON FLOTOW, Luise (1991). "Feminist Translation: Contexts, Practices, and Theories." TTR: Études sur le texte et ses transformations, IV(2), pp. 69-84.

ABSTRACT: Fidelity and The Gendered Translation - Postmodern theories of language have drastically changed the ways we view the translator's task and the relationships that can be established between the so-called original and its foreign versions. One of the most important insights brought about by such textual theories is the recognition of the translator's inescapable authorial role in the translated text. At the same time, an increasing awareness of the impact of gender-related issues to the production of meaning is beginning to encourage a promising union between feminism, contemporary textual theories, and the emerging discipline of translation studies. Such a union has begun to produce a new brand of politically motivated translations as well as an enlightening reflection on the issues of both translation and gender and to prompt some 
female translators to write about their feminist practice and strategies that explicitly subvert the original they disagree with. However, as I intend to argue, even though their work and theoretical comments do reveal that their voices have already conquered a much deserved space within the (still) predominantly essentialist scenario of patriarchal culture, they seem to be repeating some version of the same scenario which treats original and translations differently and which they rightly condemn in traditional theories of translation and gender. As they disguise their conscious intervention in the text they translate under the mask of some form of or to the same original they explicitly deconstruct, such translators fail to take their own sound insights seriously and run the unnecessary risk of jeopardizing their work.

RÉSUMÉ: Fidélité et traduction «sexuale» - Les théories postmodernes du langage ont radicalement changé la manière d'envisager la tâche du traducteur et les relations établies entre l'original et ses versions étrangères. L'un des apports les plus importants de ces théories du texte est de souligner que l'acte de traduire implique inévitablement la production des signifiés. Simultanément, la reconnaissance accrue de l'impact des facteurs sexuaux sur la production du sens est l'amorce d'une heureuse union entre le féminisme, les théories contemporaines du texte et la traductologie en émergence. Cette union a commencé à produire un nouveau type de traductions politiquement motivées, ainsi qu'une réflexion sur la traduction et les rôles sexuaux, et a incité certaines traductrices à décrire leur pratique et leurs stratégies féministes, par lesquelles elles subvertissent explicitement l'original lorsqu'il ne leur convient pas. Cependant - et telle est ma thèse -, même si leurs travaux et leurs commentaires théoriques prouvent que leur voix a déjà conquis un espace mérité dans le scénario essentialiste (encore) dominant de la culture patriarcale, elles semblent reproduire une variante du même scénario qui traite l'original et les traductions différemment, ce qu'elles condamnent pourtant dans les théories traditionnelles de la traduction et des rôles sexuaux - et avec raison. Déguisant leur intervention délibérée sous le masque d'un original - un autre ou le même, qu'elles déconstruisent de façon explicite -, elles ne prennent pas au sérieux leurs hypothèses pourtant pertinentes, ce qui risque inutilement de compromettre leurs travaux. 